\title{
Physical and functional properties of tunicate (Styela clava) hydrolysate obtained from pressurized hydrothermal process
}

\author{
Hee-Jeong Lee, Sol-Ji Chae, Periaswamy Sivagnanam Saravana and Byung-Soo Chun * (1)
}

\begin{abstract}
In this study, marine tunicate Styela clava hydrolysate was produced by an environment friendly and green technology, pressurized hot water hydrolysis $(\mathrm{PHWH})$ at different temperatures $\left(125-275^{\circ} \mathrm{C}\right)$ and pressure $50 \mathrm{bar}$. A wide range of physico-chemical and bio-functional properties such as color, $\mathrm{pH}$, protein content, total carbohydrate content, reducing sugar content, and radical scavenging activities of the produced hydrolysates were evaluated. The appearance (color) of hydrolysates varied depending on the temperature; hydrolysates obtained at $125-150^{\circ} \mathrm{C}$ were lighter, whereas at $175^{\circ} \mathrm{C}$ gave reddish-yellow, and $225^{\circ} \mathrm{C}$ gave dark brown hydrolysates. The $L^{*}$ (lightness), $a^{*}$ (red-green), and b* (yellow-blue) values of the hydrolysates varied between 35.20 and $50.21,-0.28$ and 9.59 , and 6.45 and 28.82 , respectively. The pH values of S. clava hydrolysates varied from $6.45\left(125^{\circ} \mathrm{C}\right)$ to $8.96\left(275^{\circ} \mathrm{C}\right)$ and the values were found to be increased as the temperature was increased. The hydrolysis efficiency of S. clava hydrolysate was ranged from 46.05 to $88.67 \%$ and the highest value was found at $250^{\circ} \mathrm{C}$. The highest protein, total carbohydrate content, and reducing sugar content of the hydrolysates were found $4.52 \mathrm{mg} / \mathrm{g}$ bovine, $11.48 \mathrm{mg} / \mathrm{g}$ and $2.77 \mathrm{mg} / \mathrm{g}$ at 175 , and 200 and $200{ }^{\circ} \mathrm{C}$, respectively. Hydrolysates obtained at lower temperature showed poor radical scavenging activity and the highest DPPH, ABTS, and FRAP activities were obtained 10.25, 14.06, and $10.91 \mathrm{mg}$ trolox equivalent/g hydrolysate (dry matter basis), respectively. Therefore, S. clava hydrolysate obtained by PHWH at $225-250{ }^{\circ} \mathrm{C}$ and 50 bar is recommended for bio-functional food supplement preparation.
\end{abstract}

Keywords: S. clava, Bio-functional, Hydrolysate, Pressurized hot water hydrolysis

\section{Background}

Marine resources are generally considered as health beneficial due to richness in wide range of biofunctional compounds. Recently, researchers investigated on the extraction of many bioactive compounds from various marine animals, including tunicate Styela clava (Donia and Hamann 2003). S. clava is a marine organism geographically distributed to Northwest Pacific (including Korea), northern Europe, North America, and Australia (Jumeri and Kim, 2011). It is an important mariculture species used as a popular food in Korea (Ko and Jeon 2015). The protein, lipid, carbohydrate and ash content of the flesh tissue of S. clava was reported 67.80, $6.54,16.77$, and $7.05 \%$ (dry basis), respectively (KO et al. 2012a). Several studies on S. clava have pointed out

\footnotetext{
* Correspondence: bschun@pknu.ac.kr

Department of Food Science and Technology, Pukyong National University, 45 Yongso-ro, Nam-Gu, Busan 48513, Republic of Korea
}

various bioactivities including anti-oxidative (Lee et al. 2010), anti-inflammatory (Xu et al. 2008), anticancer (Kim et al. 2006), antihypertensive (KO et al. 2012a; KO et al. 2012b), and hepato-protective effects (Xu et al. 2008; Jumeri and Kim, 2011).

Oxidation reaction in living organisms is unavoidable which generates hydrogen peroxide $\left(\mathrm{H}_{2} \mathrm{O}_{2}\right)$, singlet oxygen $\left({ }^{1} \mathrm{O}_{2}\right)$, superoxide radicals $\left(\mathrm{O}_{2}^{-} \bullet\right)$, and hydroxyl radicals $(\mathrm{OH} \bullet)$, which are commonly known as reactive oxygen species (ROS) (Wang et al. 2006). Those ROS generated from energy metabolism, stress, exogenous chemicals, or in the food systems are able to oxidize biomolecules of the cell components and cause destructive and irreversible damages (Prasad et al. 2010). The primary target site of the degradation process is the DNA, proteins, cell membranes, and vital cellular constituents which induce fatal physiological disorders including atherosclerosis, muscular dystrophy, rheumatoid arthritis, neurological 
dysfunctions, cataracts, cancer, and aging (Valko et al. 2004). Imbalance between ROS and ingested antioxidant molecules severely cause oxidative stress (Kang et al. 2017). In taking of antioxidant compounds may neutralize those ROS and guard body system from the problems. Additionally, ROS leads to rancidity, breakdown, and toxicity of functional biomolecules of food components, thus rendering qualitative degradation of foods. Peptides obtained from the breakdown of animals and plant proteins have been found to exhibit various bio-functional activities. Usually peptides are inactive when staying intact with parent proteins (Matsui et al. 2002) and exhibit various bio-functional activities once liberated, depending on their compositional, structural, and sequential properties. Hydrolysis is important for chemical decomposition in which the compounds are spitted into smaller compounds by reacting with water. Hydrolysis of protein under controlled condition generates peptides, and thus the functional properties of a protein is improved (Fujimoto et al. 2012). So, a proper hydrolysis technique at suitable and optimum conditions plays an important role in industrial bio-functional food preparations.

Present hydrolysis methods used in the industries such as chemical (acid, alkali, or catalytic) hydrolysis and enzymatic hydrolysis have several drawbacks. Violent reaction conditions, removal of chemicals from the products, and environmental pollution are the primary disadvantages of chemical hydrolysis. High operation cost and long production cycle make enzymatic hydrolysis inconvenient in industrial application. On the contrary, pressurized hot water extraction can provide a new dimension in hydrolytic reactions. Pressurized hot water extraction is done by boiling water at 100 to $374{ }^{\circ} \mathrm{C}$ under pressure (10 to 60 bar) to keep the water in a liquid condition (Saravana et al. 2016a). It is considered as environment friendly green technique which offers high extraction yield (Özel and Göğüş 2014). A number of physical and chemical changes in water at sub-critical conditions, especially in hydrogen bond, dielectric constant, ion product, etc. facilitate reactions of organic compounds and generate many valuable materials (Yoshii et al. 2001; Laria et al. 2004; Tomita and Oshima 2004; Yagasaki et al. 2005). For example, the dielectric constant of water at room temperature is 80 , which can be changed to 27 by heating at $250{ }^{\circ} \mathrm{C}$, but the liquid state can be maintained by manipulating pressure (Carr et al. 2011). Hydrolysis in subcritical water is environment friendly technology as it is free of environmental pollution (Cheng et al. 2008). At present, sub-critical water hydrolysis attracted attention for hydrolysis and conversion of biomass to useful compounds (Kruse and Gawlik 2003; Bicker et al. 2005; Uddin et al. 2010). Sub-critical water hydrolysis does not use organic solvents which ensures great advantages as organic solvents used in any process operation must be recycled, deposited, or incinerated resulting in a non-aggressive waste to the environment. Moreover, sub-critical water hydrolysis does not require biomass pretreatment; it is fast, generates lower residue, and presents lesser corrosion than conventional methods (Zhao et al. 2012).

Several studies of the bioactivities of $S$. clava, have been carried out previously which employed chemical hydrolysis, enzymatic hydrolysis, and solvent extraction methods, but there is no report regarding the hydrolysates of S. clava obtained by pressurized hot water extraction. The main objective of the study was to produce S. clava hydrolysate by pressurized hot water extraction at different temperature and pressure to optimize suitable conditions of hydrolysate regarding physical parameters (color and $\mathrm{pH}$ ) and bio-functional activities (reducing sugars, antioxidants, and antihypertensive).

\section{Methods \\ Chemicals and reagents}

2,2-azinobis-3ethylbenzothiazoline-6-sulphonic acid (ABTS), 2,2-diphenyl-1-picrylhydrazyl (DPPH), 2,4,6-tripyridyl-s-triazine (TPTZ), 6-hydroxy-2,5,7,8tetramethylchroman-2-carboxylic acid (Trolox) were purchased from Sigma-Aldrich Chemical Co. (St. Louis, MI, USA). Iron (III) chloride 6-hydrate $\left(\mathrm{FeCl}_{3} \cdot 6 \mathrm{H}_{2} \mathrm{O}\right)$, sodium acetate $\left(\mathrm{C}_{2} \mathrm{H}_{3} \mathrm{NaO}_{2} \cdot 3 \mathrm{H}_{2} \mathrm{O}\right)$ acetic acid $\left(\mathrm{C}_{2} \mathrm{H}_{4} \mathrm{O}_{2}\right)$ were purchased from Merck (Darmstadt, Hessen Germany). All other reagents used in this study were of high-performance liquid chromatography (HPLC) or analytical grade.

\section{Sample collection and preparation}

Fresh, solitary Mideodeok (S. clava) was purchased from a local market in Gosung, Gyoungnam Province, Korea. Upon arrival at the laboratory the samples were immediately dissected and rinsed with tap water to remove the contaminants and then the tunics were separated from the muscle and frozen at $-40{ }^{\circ} \mathrm{C}$. The frozen samples were freeze dried at $-113{ }^{\circ} \mathrm{C}$ for about $72 \mathrm{~h}$ then freezedried sample was milled using mechanical blender and sieved to pass $710 \mu \mathrm{m}$ sieve, filled in airtight plastic bag and kept in refrigerator at $-40{ }^{\circ} \mathrm{C}$ until needed for further analysis.

\section{Pressurized hot water hydrolysis (PHWH)}

The PHWH was performed in a $200-\mathrm{cm}^{3}$ batch reactor made of 276 Hastelloy with temperature control (Fig. 1). Freeze-dried $S$. clava powder and water $(1: 30 \mathrm{w} / \mathrm{v})$ was loaded into the reactor. Then the reactor was closed and heated using an electric heater to the required temperature $\left(125-275{ }^{\circ} \mathrm{C}\right)$ and pressures of 50 bar. The temperature and pressure in the reactor were controlled 


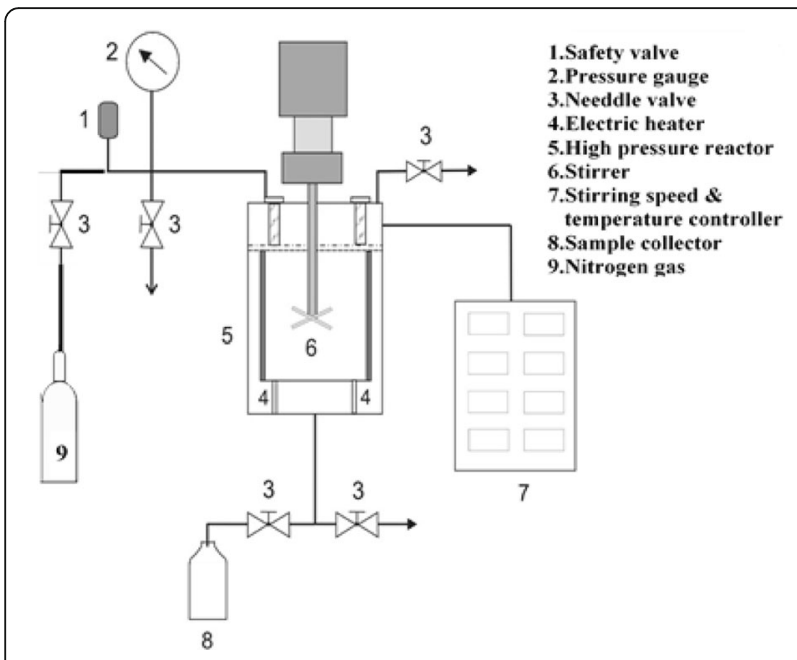

Fig. 1 Flow diagram of pressurized hot water hydrolysis experimental apparatus

using a temperature controller and pressure gauge, respectively. The sample was stirred using a four-blade stirrer at $150 \mathrm{rpm}$. The reaction time was recorded after the set temperature and pressers were achieved and it was $5 \mathrm{~min}$ for each condition. After the end of the reaction, the hydrolysate samples from the reactor were collected and filtered using Whatman nylon membrane filter $(0.45 \mu \mathrm{m})$ lyophilized and stored at $4{ }^{\circ} \mathrm{C}$ until needed for analysis. The hydrolysis yield was calculated using the following reaction:

$\begin{aligned} \text { Yield }(\%)= & \frac{(\text { Mass of samle before hydrolysis })-(\text { Mass of residue after hydrolysis })}{\text { Mass of sample before hydrolysis }} \\ & \times 100\end{aligned}$

To compare the PHWH, a control was kept by having a room temperature extraction for $18 \mathrm{~h}$ with the same ratio and after the extraction process, same process was carried out as before for the PHWH extracts.

\section{Protein content}

The protein content of the soluble product was analyzed by Lowry's assay (Lowry et al. 1951), using bovine serum albumin (BSA) as a standard.

\section{Total carbohydrate content}

The total carbohydrate content was determined by using anthrone reagent following the method reported by Carroll et al. (1956).

\section{Reducing sugar content}

The reducing sugars content was analyzed by dinitrosalicylic (DNS) colorimetric method (Miller 1959), using D-glucose as a standard. For each of the $3 \mathrm{ml}$ of the sample, $3 \mathrm{~mL}$ of DNS reagent was added. The mixture was then heated in boiling water for 5 min until the redbrown color developed. Then, $1 \mathrm{~mL}$ of $40 \%$ potassium sodium tartrate (Rochelle salt) solution was added to stabilize the color, after which the mixture was cooled to room temperature in a water bath. The absorbance was then measured with a spectrophotometer at $575 \mathrm{~nm}$.

\section{Antioxidant activity analysis DPPH radical scavenging activity}

The stable free radical scavenging activity was determined by DPPH • assay according to the method of Thitilertdecha et al. (2008). One $\mathrm{mL}$ of $60 \mathrm{mM} \mathrm{DPPH} \bullet$ solution in ethanol was mixed with $3 \mathrm{~mL}$ of sample at different concentrations. The control consisted of $1 \mathrm{~mL}$ of $\mathrm{DPPH} \bullet$ solution and $3 \mathrm{~mL}$ of ethanol. The mixture was incubated at room temperature for $30 \mathrm{~min}$, and the absorbance was measured at $517 \mathrm{~nm}$. The ability to scavenge DPPH radicals was calculated as the DPPH• scavenging by the following equation:

$$
\% \mathrm{DPPH} \bullet \text { scavenging }=[(\mathrm{A} 0-\mathrm{A} 1) / \mathrm{A} 0] \times 100
$$

where A0 is absorbance of the control and A1 is the absorbance of the mixture containing the sample. Trolox were used as positive control.

\section{$\mathrm{ABTS}^{+}$radical cation scavenging activity}

$\mathrm{ABTS}^{\bullet+}$ radical scavenging activity was determined according to the modified method of Re et al. (1999). ABTS + was produced by reacting $7 \mathrm{mM}$ aqueous ABTS + solution with $2.45 \mathrm{mM}$ potassium persulfate in the dark at room temperature for $16 \mathrm{~h}$ and was used within 2 days. The ABTS + solution was diluted with ethanol to an absorbance of $(0.70 \pm 0.02)$ at $734 \mathrm{~nm}$. One $\mathrm{mL}$ of diluted sample was mixed with $3 \mathrm{~mL}$ of diluted ABTS $\bullet+$ solution. The mixture was then allowed to stand for $20 \mathrm{~min}$ at room temperature, and the absorbance was immediately recorded at $734 \mathrm{~nm}$. Standard curve was constructed using standard concentrations of Trolox.

\section{The FRAP assay}

The FRAP (ferric reducing antioxidant power) assay was done according to Benzie and Strain (1996) with some modifications. Briefly, acetate buffer $300 \mathrm{mM}$ $(\mathrm{pH}$ 3.6) was prepared by mixing $3.1 \mathrm{~g}$ of $\mathrm{C}_{2} \mathrm{H}_{3} \mathrm{NaO}_{2} \cdot 3 \mathrm{H}_{2} \mathrm{O}$ and $16 \mathrm{~mL} \mathrm{C}_{2} \mathrm{H}_{4} \mathrm{O}_{2}$ in $1 \mathrm{~L}$ deionized water, $10 \mathrm{mM}$ TPTZ (2, 4, 6-tripyridyls-triazine) in $40 \mathrm{mM} \mathrm{HCl} ; 20 \mathrm{mM} \mathrm{FeCl} 3 \cdot 6 \mathrm{H}_{2} \mathrm{O}$. Working FRAP reagent was prepared as required by mixing $25 \mathrm{~mL}$ acetate buffer, $2.5 \mathrm{~mL}$ TPTZ solution, and $2.5 \mathrm{~mL}$ $\mathrm{FeCl}_{3} \cdot 6 \mathrm{H}_{2} \mathrm{O}$ solution. The standard curve was linear between 5 to $500 \mu \mathrm{g} / \mathrm{mL}$ Trolox. 


\section{Statistical analysis}

Statistical analysis was performed using SPSS (Version 20 for windows, IBM, Chicago, IL, USA).

\section{Results and discussion \\ Color and $\mathrm{pH}$ of hydrolysates}

The appearance of S. clava hydrolysates attained by PHWH process varied depending on the usage of various temperature (Fig. 2, Table 1). The brown color of extracts was more intense at higher treatment temperatures. Extracts obtained at 125 and $150{ }^{\circ} \mathrm{C}$ were light white, whereas extracts prepared at $175{ }^{\circ} \mathrm{C}$ were reddish-yellow. Hydrolysate obtained at higher temperatures progressively became brownish-yellow, and the $225{ }^{\circ} \mathrm{C}$ hydrolysate was dark brown, while the control $\left(25^{\circ} \mathrm{C}\right)$ showed a pale white color.

The $\mathrm{pH}$ of the obtained S. clava hydrolysate was measured and values were shown in the Table 1 . The $\mathrm{pH}$ values were varied from $6.45\left(125{ }^{\circ} \mathrm{C}\right)$ to $8.96\left(275{ }^{\circ} \mathrm{C}\right)$ in the $S$. clava hydrolysate and the values were found to be increased as the temperature was increased. Initially, the $\mathrm{pH}$ was 6.45 for lower temperature, when the temperature increased the $\mathrm{pH}$ reduce to 5.04 at $200{ }^{\circ} \mathrm{C}$. After that the $\mathrm{pH}$ gradually increased as the temperature increases. The $\mathrm{pH}$ is increased at the high temperature due to the formation of the salts and degradation of the all the matters. The low $\mathrm{pH}$ is a result of sugars degradation into organic acids and these organic acids react in chain, providing the acidity for speeding up the subsequent reactions as an autocatalytic process (Sasaki et al. 1998).

Color is a very important quality parameter in food industry. As respects to color coordinates (Table 1) lightness $\left(L^{*}\right)$ values ranged from 35.20 to 50.21 for different condition of the hydrolysates. High lightness is due to the pigments presence and some hygroscopic substances are increase, when a sample is treated thermally and its lightness value is increased. The coordinates $\mathrm{a}^{*}$ (red-green) showed values ranged from -0.28 to 9.59 while for the coordinate $b^{*}$ (yellow-blue) the values ranged from 6.45 to 28.82 .

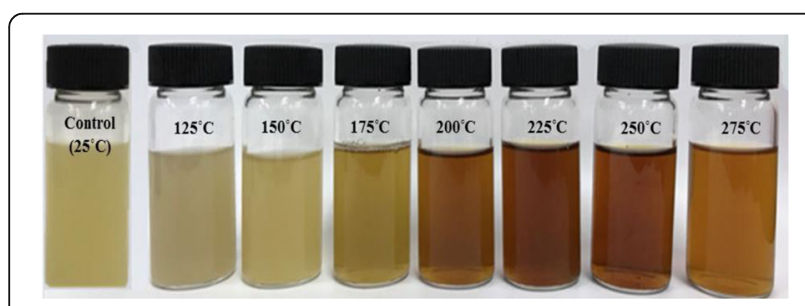

Fig. 2 Effect of temperature on the appearance of the hydrolysates
Table 1 Color and pH of hydrolysates at different temperatures

\begin{tabular}{lllll}
\hline $\begin{array}{llll}\text { Conditions } \\
\left({ }^{\circ} \mathrm{C}\right)\end{array}$ & \multicolumn{2}{l}{ Color } & $\mathrm{pH}$ \\
\cline { 2 - 4 } & $\mathrm{L}^{*}$ & $\mathrm{a}^{*}$ & \multicolumn{1}{l}{$\mathrm{b}^{*}$} & \\
\hline Control (25) & $41.26 \pm 0.14^{\mathrm{d}}$ & $1.20 \pm 0.08^{\mathrm{f}}$ & $5.94 \pm 1.23^{\mathrm{d}}$ & $6.38 \pm 1.21^{\mathrm{d}}$ \\
125 & $42.39 \pm 0.67^{\mathrm{d}}$ & $1.27 \pm 0.13^{\mathrm{f}}$ & $6.45 \pm 0.20^{\mathrm{d}}$ & $6.45 \pm 0.07^{\mathrm{d}}$ \\
150 & $50.21 \pm 0.92^{\mathrm{a}}$ & $-0.28 \pm 0.07^{\mathrm{d}}$ & $12.31 \pm 0.06^{\mathrm{c}}$ & $5.51 \pm 0.01^{\mathrm{e}}$ \\
175 & $49.30 \pm 0.04^{\mathrm{b}}$ & $1.83 \pm 0.05^{\mathrm{e}}$ & $21.47 \pm 0.07^{\mathrm{b}}$ & $5.35 \pm 0.03^{\mathrm{f}}$ \\
200 & $36.72 \pm 0.28^{\mathrm{d}}$ & $7.28 \pm 0.02^{\mathrm{d}}$ & $14.03 \pm 0.24^{\mathrm{c}}$ & $5.04 \pm 0.01^{\mathrm{g}}$ \\
225 & $35.20 \pm 0.37^{\mathrm{f}}$ & $9.59 \pm 0.12^{\mathrm{a}}$ & $12.05 \pm 0.35^{\mathrm{c}}$ & $6.74 \pm 0.03^{\mathrm{c}}$ \\
250 & $47.32 \pm 0.10^{\mathrm{c}}$ & $9.22 \pm 0.09^{\mathrm{b}}$ & $28.29 \pm 0.08^{\mathrm{a}}$ & $8.58 \pm 0.00^{\mathrm{b}}$ \\
275 & $50.09 \pm 0.15^{\mathrm{ab}}$ & $8.44 \pm 0.06^{\mathrm{c}}$ & $28.82 \pm 0.72^{\mathrm{a}}$ & $8.96 \pm 0.02^{\mathrm{a}}$ \\
\hline
\end{tabular}

Values are mean \pm SD. Values with different superscript letters within rows indicate statistical significant difference $(P \leq 0.05)$ as determined by Duncan's multiple range test

\section{Hydrolysis efficiency}

The conditions used in PHWH ranged from 125 to $275{ }^{\circ} \mathrm{C}$ with a reaction time of $5 \mathrm{~min}$ and pressure was maintained 50 bar for all the conditions. The product obtained after reaching room temperature was normally a mixture of water and solids sorted in a matrix consisting of two layers due to precipitation of particles after extraction. The upper layer comprised of a less viscous aqueous solution with very low turbidity, while the lower layer was predominantly wet S. clava residue. The aroma of the hydrolysate was somehow toasty for lower temperature conditions when the temperature is increased the aroma was turned to be a pungent. This change in aroma with increasing temperature was also reported by Saravana et al. (2016a) for hydrolysates of Saccharina japonica using PHWH. The hydrolysis efficiency of $S$. clava hydrolysate ranged from 46.05 to $88.67 \%$ (Fig. 3), while the control $\left(25{ }^{\circ} \mathrm{C}\right)$ showed a extraction yield of $40 \%$. In the present study, it is shown that hydrolysis efficiency for S. clava hydrolysate increased consistently with increasing temperature. This was considered by improved mass transfer rate, increase in solubility of the analytes, and decrease in solvent viscosity and surface tension that take place due to increasing temperature and pressure under subcritical conditions (Herrero et al. 2015). Previous work by Asaduzzaman and Chun (2014) with Scomber japonicus using the same $\mathrm{PHWH}$ apparatus reported similar results for hydrolysis efficiency. Thus, increasing temperature and pressure conditions facilitate deeper penetration of solvent into the sample matrix which enhanced greater surface contact and improved mass transfer to the solvent. PHWH technique has been adapted for various biomasses, including proteins, carbohydrates and fatty acids, and the yield and form of hydrolysate differ depending on the reaction conditions, including the original source, particle size, temperature, pressure, hydrolysis time, etc. (Rogalinski et al. 2008). 


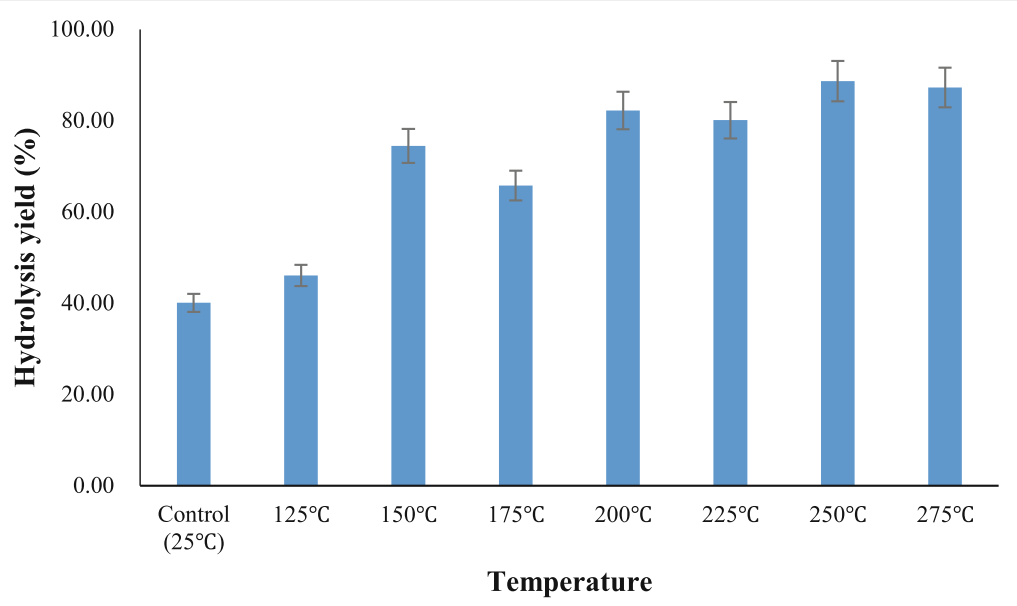

Fig. 3 Effect of temperature on hydrolysis yield of S. clava

While it has been reported that the hydrolysate yield and form change can be affected by temperature, pressure, and hydrolysis time, few studies have reported that the hydrolysate yield can be altered by use of different particle sizes (Toor et al. 2011).

Total protein, total carbohydrate, and reducing sugar content Total protein for S. clava hydrolysate increased from 125 to $175{ }^{\circ} \mathrm{C}$ but decreased slightly as temperature increased further (Fig. 4). Watchararuji et al. (2008) stated that protein content improved with a raise in temperature up to $220{ }^{\circ} \mathrm{C}$ for rice bran by $\mathrm{PHWH}$. Generally, the rise in protein content with increasing temperature in $\mathrm{PHWH}$ is due to a change in polarity of water in the subcritical region. According to Thiruvenkadam et al. (2015), the increase in dielectric constant and the decrease in density $\left(1 \mathrm{~g} / \mathrm{cm}^{3}\right.$ at $25{ }^{\circ} \mathrm{C}$ to $0.75 \mathrm{~g} / \mathrm{m}^{3}$ at $300{ }^{\circ} \mathrm{C}$ ) compared to ambient conditions consequently enable hydrocarbons to become more water soluble. This is characterized by breakdown of hydrogen bonding in the water molecules which changes the polarity of water in the subcritical region from complete polarity to moderately non-polar. This condition tends to enhance the attraction of water towards non-polar hydrocarbons thus increases miscibility and enhances hydrocarbon solubility in water. However, the decrease of proteins after $250{ }^{\circ} \mathrm{C}$ was most probably due to denaturing as a result of exceedingly high temperatures. Actually, proteins can be denatured by heat when their resistance to thermal denaturation capacity is exceeded (Haque et al. 2016). Thus, this study showed that the best condition for utilizing proteins from S. clava by PHWH is around $175{ }^{\circ} \mathrm{C}$ with a high yield of $4.24 \mathrm{mg} / \mathrm{g}$. These observations suggest that proteinaceous substances are the main components in the extracts obtained at higher temperatures. However, the decrease of protein content at 220 and $240{ }^{\circ} \mathrm{C}$ suggested that at these temperatures degrade the proteins and the generation of small components,

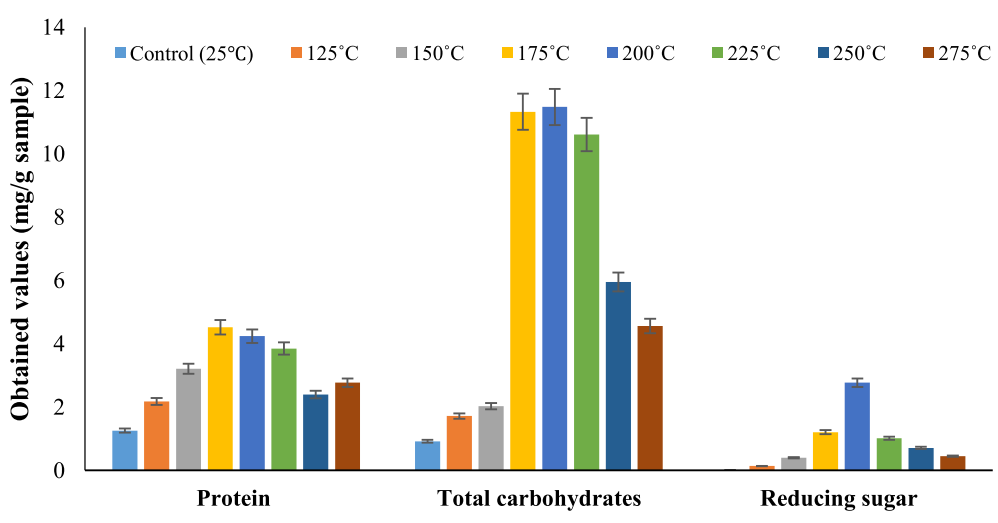

Fig. 4 Protein, total carbohydrate, and reducing sugar content of S. clava hydrolysates 
such as organic acids, were produced (Saravana et al. 2016b).

The highest yield of total carbohydrate content was obtained at $200{ }^{\circ} \mathrm{C}$, after that the composition was gradually decreased as the temperature increases. At $200{ }^{\circ} \mathrm{C}$ the total carbohydrate content was $11.48 \mathrm{mg} / \mathrm{g}$ (Fig. 4). Recent report says the total carbohydrate content in the S. clava can be altered throughout the season and it was found high in March with a range from 21.6 to $25.9 \%$ (Lee et al. 2006). The highest yields for reducing sugar were recovered at condition $200{ }^{\circ} \mathrm{C}$ (Fig. 4). All sugars were higher at milder conditions but decreased gradually as temperature and pressure increased. Quitain et al. (2002) stated that the reducing sugar content was dropped as the temperature and reaction time increases and this is perhaps due to the degradation into other products such as ketones/aldehydes, and it could lead to produce the organic acids. Therefore, PHWH treatment without acid or base catalyst is a promising step towards bioethanol production.

\section{Antioxidant activities \\ $D P P H$ radical scavenging activity}

$\mathrm{DPPH}$, can easily undergo reduction by an antioxidant and it is a stable radical with a maximum absorbance at $517 \mathrm{~nm}$. Liu et al. (2010) and Peng et al. (2009) stated that DPPH a proton-donating can change color from purple to yellow by scavenging the substance $\left(\mathrm{H}^{+}\right)$and the absorbance is reduced. All hydrolysates effectively showed DPPH activity (Fig. 5a). The decline of DPPH in the incidence of the $S$. clava hydrolysates shows that mixed peptide/amino acids were capable of reducing DPPH apparently by combination the odd electron of the DPPH radicals. The DPPH assay was expressed in terms of trolox equivalent and the high antioxidant activity was found at $225{ }^{\circ} \mathrm{C}$ (Trolox equivalent $10.20 \mathrm{mg} / \mathrm{g}$ sample) after that the activity was decreased. From the obtained results, S. clava hydrolysate has the capability to efficiently reduce DPPH radical, which shows that the hydrolysates are good antioxidant compounds with radical scavenging activity. No $\mathrm{DPPH}$ activity was found for control extract. Wu et al. 2003 distinguished that for mackerel hydrolysates, DPPH scavenging activity enriched progressively with increasing hydrolysis time. During hydrolysis, a varied amount of smaller peptides and free amino acids are produced, depending upon the temperature conditions. The changes in size, composition of amino acids can have an effect in the antioxidant activity (Wu et al. 2003). Earlier studies have shown that high DPPH or other radical scavenging activities of protein hydrolysates or peptides are frequently related with vastly hydrophobic amino acids or overall hydrophobicity (Li et al. 2008).

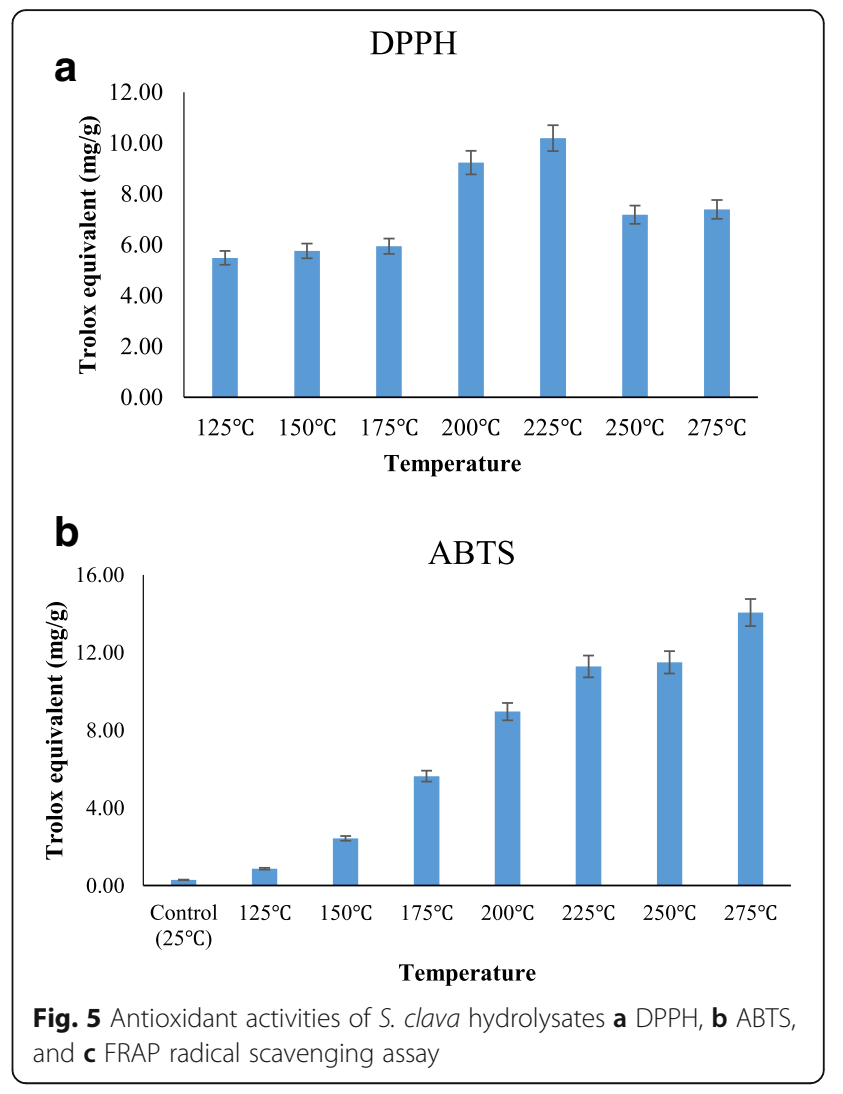

\section{ABTS $^{\bullet+}$}

ABTS antioxidant activity was found to be increased as the temperature increases, S. clava hydrolysate showed high antioxidant activity at $275{ }^{\circ} \mathrm{C}$ and the amount of ABTS $^{\bullet+}$ antioxidant was ranged from $0.86-14.06 \mathrm{mg} / \mathrm{g}$ Trolox equi (Fig. 5b), for the control extract a very low activity was found. The alterations in $\mathrm{ABTS}^{\bullet+}$ scavenging activity between the hydrolysates valor due to the changes in sequence length and amino acid composition. Normally, every hydrolysate which consists of proteins that can act as hydrogen donors and react with radicals, altering them into more stable products and thereby ending the radical chain reaction. Free radical reducing has been described to have the chief antioxidative mechanism of peptides due to amino acids such as Ala, Tyr, and Leu. Even though protein hydrolysates were the key point of this work, other substances in S. clava, such as phenolics, might have extracted together with protein and that could have contributed to the antioxidant activity of the crude hydrolysates (Jumeri and Kim, 2011).

\section{FRAP}

The FRAP assay is a rapid, simple, dependable and inexpensive method extensively used in most of the research laboratory where antioxidant capacity measurement is carried out (Apak et al. 2007). The FRAP of the $S$. clava hydrolysate was measured as the ability to 
reduce $\mathrm{Fe}^{3+}$ to $\mathrm{Fe}^{2+}$, which indicated the capacity of antioxidants to donate an electron or hydrogen, and an increase in absorbance at $700 \mathrm{~nm}$ indicated greater reducing power. As showed in Fig. $5 \mathrm{c}, 225^{\circ} \mathrm{C}$ hydrolysate showed a high FRAP absorbance of $10.91 \mathrm{mg} / \mathrm{g}$. No antioxidant activity was found using FRAP test for control extract.

The FRAP result indicates that antioxidant activity increases as the temperature increases after $225{ }^{\circ} \mathrm{C}$ the activity decreased gradually. Many studies reported that protein hydrolysates from other sources possessed strong FRAP. Fish protein hydrolysates from smooth hound muscle protein and yellow stripe trevally were reported to have FRAP values of 0.60 at $2.0 \mathrm{mg} / \mathrm{g}$ and 0.52 at $3.6 \mathrm{mg} / \mathrm{g}$, respectively (Bougatef et al. 2009; Klompong et al. 2007). Additionally, only one research for the FRAP of abalone viscera hydrolysates by alkali protease, papain, neutral protease, pepsin, and trypsin was reported by Zhou et al. (2012), and abalone viscera hydrolysates exhibited the FRAP value of below 0.90 at $10.0 \mathrm{mg} / \mathrm{g}$.

\section{Conclusions}

The results of this study indicate that temperature has great influence on the physico-chemical and biofunctional properties on the PHWH of S. clava. The highest DPPH and FRAP activities were obtained in the hydrolysate at $225^{\circ} \mathrm{C}$, while ABTS activity showed highest activity at $275{ }^{\circ} \mathrm{C}$. The highest protein, total carbohydrate, and reducing sugar content of the hydrolysates were found at 175,150 , and $200{ }^{\circ} \mathrm{C}$, respectively. So, PHWH of S. clava at $225^{\circ} \mathrm{C}$ and 50 bar can produce high antioxidant activity. Therefore, $\mathrm{PHWH}$ have the potential to produce functional compounds from S. clava, which can be used as antioxidant supplement in food industry.

\section{Abbreviations}

ABTS: 2,2-azinobis-3ethylbenzothiazoline-6-sulphonic acid; DPPH: 2,2diphenyl-1-picrylhydrazyl; FRAP: Ferric reducing antioxidant power; PHWH: Pressurized hot water hydrolysis; TPTZ: 2,4,6-tripyridyl-s-triazine; Trolox: 6-hydroxy-2,5,7,8-tetramethylchroman-2-carboxylic acid

\section{Acknowledgements}

This work was supported by Business for Cooperative R\&D between Academy and Research Institute funded by Korea Small and Medium Administration in 2016 project number (C0406103).

\section{Funding}

This study was funded by the Business for Cooperative R\&D between Academy and Research Institute funded by Korea Small and Medium Administration in 2016 project number (C0406103).

\section{Availability of data and materials}

All datasets in this study are available from the corresponding author on reasonable request.

\section{Authors' contributions}

HJL, SJC PSS, and BSC designed the study. PSS wrote the article. HJL, SJC PSS, and BSC performed the experiment. HJL and SJC analyzed and interpreted the data. All authors have read, commented upon, and approved the final article.
Ethics approval and consent to participate

Not applicable.

\section{Consent for publication}

The manuscript has been read and approved by the authors, and none of its parts have been submitted and published elsewhere. The authors also declare that nobody who qualifies for authorship has been excluded from the list of authors.

\section{Competing interests}

The authors declare that they have no competing interests.

\section{Publisher's Note}

Springer Nature remains neutral with regard to jurisdictional claims in published maps and institutional affiliations.

Received: 4 May 2017 Accepted: 6 July 2017

Published online: 19 July 2017

\section{References}

Apak R, Güçlü K, Demirata B, Özyürek M, Çelik SE, Bektaşoğlu B. Comparative evaluation of various total antioxidant capacity assays applied to phenolic compounds with the CUPRAC assay. Molecules. 2007;12(7):1496-547.

Asaduzzaman A, Chun B-S. Hydrolyzates produced from mackerel Scomber japonicus skin by the pressurized hydrothermal process contain amino acids with antioxidant activities and functionalities. Fisheries Sci. 2014;80(2):369-80.

Benzie IF, Strain JJ. The ferric reducing ability of plasma (FRAP) as a measure of "antioxidant power": the FRAP assay. Anal Biochem. 1996;239(1):70-6.

Bicker M, Endres S, Ott L, Vogel H. Catalytical conversion of carbohydrates in subcritical water: A new chemical process for lactic acid production. J Mol Catal A Chem. 2005;239(1):151-7.

Bougatef A, Hajij M, Balti R, Lassoued I, Triki-Ellouz Y, Nasri M. Antioxidant and free radical-scavenging activities of smooth hound (Mustelus mustelus) muscle protein hydrolysates obtained by gastrointestinal proteases. Food Chem. 2009;114(4):1198-205.

Carr AG, Mammucari R, Foster N. A review of subcritical water as a solvent and its utilisation for the processing of hydrophobic organic compounds. Chem Eng J. 2011;172(1):1-17.

Carroll NV, Longley RW, Roe JH. The determination of glycogen in liver and muscle by use of anthrone reagent. J Biol Chem. 1956;220:583-93.

Cheng H, Zhu X, Zhu C, Qian J, Zhu N, Zhao L, et al. Hydrolysis technology of biomass waste to produce amino acids in sub-critical water. Bioresour Technol. 2008;99(9):3337-41.

Donia M, Hamann MT. Marine natural products and their potential applications as anti-infective agents. Lancet Infect Dis. 2003;3(6):338-48.

Fujimoto K, Yoshii N, Okazaki S. Free energy profiles for penetration of methane and water molecules into spherical sodium dodecyl sulfate micelles obtained using the thermodynamic integration method combined with molecular dynamics calculations. J Chem Phys. 2012;136(1):014511.

Jumeri, Kim SM. Antioxidant and anticancer activities of enzymatic hydrolysates of solitary tunicate (Styela clava). Food Sci Biotechnol. 2011;20(4):1075-85.

Haque MA, Timilsena BYP, Adhikari B. Food Proteins, Structure, and Function. 2016.

Herrero M, del Pilar S-CA, Cifuentes A, Ibáñez E. Plants, seaweeds, microalgae and food by-products as natural sources of functional ingredients obtained using pressurized liquid extraction and supercritical fluid extraction. TrAC Trend Anal Chem. 2015;71:26-38.

Kang N, Kim S-Y, Rho S, Ko J-Y, Jeon Y-J. Anti-fatigue activity of a mixture of seahorse (Hippocampus abdominalis) hydrolysate and red ginseng. Fish Aqua Sci. 2017;20(1):3.

Kim J-J, Kim S-J, Kim S-H, Park H-R, Lee S-C. Antioxidant and anticancer activities of extracts from Styela clava according to the processing methods and solvents. J Korean Soc Food Sci Nutr. 2006;35(3):278-83.

Klompong V, Benjakul S, Kantachote D, Shahidi F. Antioxidative activity and functional properties of protein hydrolysate of yellow stripe trevally (Selaroides leptolepis) as influenced by the degree of hydrolysis and enzyme type. Food Chem. 2007;102(4):1317-27.

Ko S-C, Jeon Y-J. Anti-inflammatory effect of enzymatic hydrolysates from Styela clava flesh tissue in lipopolysaccharide-stimulated RAW 264.7 macrophages and in vivo zebrafish model. Nutr Res Pract. 2015;9(3):219-26.

Ko S-C, Lee J-K, Byun H-G, Lee S-C, Jeon Y-J. Purification and characterization of angiotensin 1 -converting enzyme inhibitory peptide from enzymatic hydrolysates of Styela clava flesh tissue. Process Biochem. 2012a;47(1):34-40. 
Ko S-C, Kim DG, Han C-H, Lee YJ, Lee J-K, Byun H-G. Nitric oxide-mediated vasorelaxation effects of anti-angiotensin l-converting enzyme (ACE) peptide from Styela clava flesh tissue and its anti-hypertensive effect in spontaneously hypertensive rats. Food Chem. 2012b;134(2):1141-5.

Kruse A, Gawlik A. Biomass conversion in water at 330-410 C and 30-50 MPa. Identification of key compounds for indicating different chemical reaction pathways. Ind Eng Chem Res. 2003;42(2):267-79.

Laria D, Martí J, Guardia E. Protons in supercritical water: a multistate empirical valence bond study. J Am Chem Soc. 2004;126(7):2125-34.

Lee J-S, Kang S-J, Choi B-D. Seasonal variation in the nutritional content of Mideodeok Styela clava. Fish Aqua Sci. 2006;9(2):49-56.

Lee D-W, You D-H, Yang E-K, Jang I-C, Bae M-S, Jeon Y-J. Antioxidant and ACE inhibitory activities of Styela clava according to harvesting time. J Korean Soc Food Sci Nutr. 2010;39(3):331-6.

Li Y, Jiang B, Zhang T, Mu W, Liu J. Antioxidant and free radical-scavenging activities of chickpea protein hydrolysate (CPH). Food Chem. 2008;106(2): 444-50.

Liu Q, Kong B, Xiong YL, Xia X. Antioxidant activity and functional properties of porcine plasma protein hydrolysate as influenced by the degree of hydrolysis. Food Chem. 2010;118(2):403-10.

Lowry OH, Rosebrough NJ, Farr AL, Randall RJ. Protein measurement with the Folin phenol reagent. J Biol Chem. 1951;193(1):265-75.

Matsui T, Yukiyoshi A, Doi S, Sugimoto H, Yamada H, Matsumoto K. Gastrointestina enzyme production of bioactive peptides from royal jelly protein and their antihypertensive ability in SHR. J Nutr Biochem. 2002;13(2):80-6.

Miller GL. Use oi Dinitrosalicylic Acid Reagent tor Determination oi Reducing Sugar. Anal Chem. 1959;31(3):426-8.

Özel MZ, Göğüş F. Subcritical water as a green solvent for plant extraction. In: Chemat F, Vian MA, editors. Alternative Solvents for Natural Products Extraction. Berlin: Springer-Verlag; 2014. p. 73-89.

Peng $X$, Xiong YL, Kong B. Antioxidant activity of peptide fractions from whey protein hydrolysates as measured by electron spin resonance. Food Chem. 2009;113(1):196-201.

Prasad KN, Xie H, Hao J, Yang B, Qiu S, Wei X, et al. Antioxidant and anticancer activities of 8-hydroxypsoralen isolated from wampee [Clausena lansium (Lour.) Skeels] peel. Food Chem. 2010;118(1):62-6.

Quitain AT, Faisal M, Kang K, Daimon H, Fujie K. Low-molecular-weight carboxylic acids produced from hydrothermal treatment of organic wastes. J Hazard Mater. 2002;93(2):209-20.

Re R, Pellegrini N, Proteggente A, Pannala A,Yang M, Rice-Evans C. Antioxidant activity applying an improved ABTS radical cation decolorization assay. Free Radic Biol Med. 1999; 26: 1231-1237.

Rogalinski T, Ingram T, Brunner G. Hydrolysis of lignocellulosic biomass in water under elevated temperatures and pressures. J Supercrit Fluids. 2008;47(1):54-63.

Saravana PS, Choi JH, Park YB, Woo HC, Chun BS. Evaluation of the chemical composition of brown seaweed (Saccharina japonica) hydrolysate by pressurized hot water extraction. Algal Res. 2016a;13:246-54.

Saravana PS, Getachew AT, Ahmed R, Cho Y-J, Lee Y-B, Chun B-S. Optimization of phytochemicals production from the ginseng by-products using pressurized hot water: Experimental and dynamic modelling. Biochem Eng J. 2016b;113: 141-51.

Sasaki M, Kabyemela B, Malaluan R, Hirose S, Takeda N, Adschiri T, et al. Cellulose hydrolysis in subcritical and supercritical water. J Supercrit Fluids. 1998;13(1): 261-8.

Thiruvenkadam S, Izhar S, Yoshida H, Danquah MK, Harun R. Process application of Subcritical Water Extraction (SWE) for algal bio-products and biofuels production. Appl Energy. 2015;154:815-28.

Thitilertdecha N, Teerawutgulrag A, Rakariyatham N. Antioxidant and antibacterial activities of Nephelium lappaceum L. extracts. LWT-Food Sci Technol. 2008; 41(10):2029-35

Tomita K, Oshima Y. Stability of manganese oxide in catalytic supercritical water oxidation of phenol. Ind Eng Chem Res. 2004;43(24):7740-3.

Toor SS, Rosendahl L, Rudolf A. Hydrothermal liquefaction of biomass: a review of subcritical water technologies. Energy. 2011;36(5):2328-42.

Uddin M, Ahn H-M, Kishimura H, Chun B-S. Production of valued materials from squid viscera by subcritical water hydrolysis. J Environ Biol. 2010;31(5):675-9.

Valko M, Izakovic M, Mazur M, Rhodes CJ, Telser J. Role of oxygen radicals in DNA damage and cancer incidence. Mol Cell Biochem. 2004;266(1-2):37-56.

Wang L, Tu Y-C, Lian T-W, Hung J-T, Yen J-H, Wu M-J. Distinctive antioxidant and antiinflammatory effects of flavonols. J Agric Food Chem. 2006;54(26):9798-804.
Watchararuji K, Goto M, Sasaki M, Shotipruk A. Value-added subcritical water hydrolysate from rice bran and soybean meal. Bioresour Technol. 2008;99(14): 6207-13.

Wu H-C, Chen H-M, Shiau C-Y. Free amino acids and peptides as related to antioxidant properties in protein hydrolysates of mackerel (Scomber austriasicus). Food Res Int. 2003;36(9):949-57.

Xu C-X, Jin H, Chung Y-S, Shin J-Y, Woo M-A, Lee K-H, et al. Chondroitin sulfate extracted from the Styela clava tunic suppresses TNF-a-induced expression of inflammatory factors, VCAM-1 and iNOS by blocking Akt/NF-kB signal in JB6 cells. Cancer Lett. 2008;264(1):93-100.

Yagasaki T, Iwahashi K, Saito S, Ohmine I. A theoretical study on anomalous temperature dependence of p K w of water. J Chem Phys. 2005;122(14): 144504.

Yoshii N, Miura S, Okazaki S. Free energy profiles for penetration of methane and water molecules into spherical sodium dodecyl sulfate micelles obtained using the thermodynamic integration method combined with molecular dynamics calculations. Chem Phys Lett J. 2001;345:195-200.

Zhao Y, Lu W-J, Wu H-Y, Liu J-W, Wang H-T. Optimization of supercritical phase and combined supercritical/subcritical conversion of lignocellulose for hexose production by using a flow reaction system. Bioresour Technol. 2012; 126:391-6.

Zhou D-Y, Zhu B-W, Qiao L, Wu H-T, Li D-M, Yang J-F, et al. In vitro antioxidant activity of enzymatic hydrolysates prepared from abalone (Haliotis discus hannai Ino) viscera. Food Bioprod Process. 2012;90(2):148-54.

\section{Submit your next manuscript to BioMed Central and we will help you at every step:}

- We accept pre-submission inquiries

- Our selector tool helps you to find the most relevant journal

- We provide round the clock customer support

- Convenient online submission

- Thorough peer review

- Inclusion in PubMed and all major indexing services

- Maximum visibility for your research

Submit your manuscript at www.biomedcentral.com/submit
) Biomed Central 